\title{
EKSTRAKSI ANTOSIANIN PADA BUNGA TELANG (CLITORIA TERNATEA L.): SEBUAH ULASAN
}

\author{
Muhammad Rifqi \\ Teknologi Pangan dan Gizi, Fakultas Ilmu Pangan Halal, Universitas Djuanda Bogor \\ Jl. Tol Ciawi no 1 Ciawi, Bogor, 16720, Indonesia
}

Email : rifqimuhammadsuryana@gmail.com

\begin{abstract}
Abstrak
Antosianin merupakan suatu senyawa yang membentuk zat warna alami pada tumbuhan dalam memberikan warna orange, merah, serta ungu. Antosianin dapat kita temukan pada tumbuhan berwarna merah, ungu, merah gelap seperti pada buah berry serta tanaman hias seperti bunga telang. Bunga telang memiliki potensi yang cukup tinggi bagi inudustri pangan diantaranya digunakan sebagai pewarna makanan serta digunakan sebagai obat tradisional. Proses ekstraksi antosianin pada bunga telang dengan menggunakan metode yang berbeda menghasilkan ekstrak dengan total antosianin yang berbeda-beda. Kedepanya perlu dilakukan penelitian lebih lanjut untuk dapay mengekstrak antosianin pada bunga telang sehingga menghasilkan ekstrak dengan total antosianin tinggi serta tidak mudah rusak.
\end{abstract}

Keywords: Antosianin; Ekstraksi Antosianin; Pangan Fungsional

\begin{abstract}
Anthocyanin is a compound that forms natural dyes in plants in giving colors orange, red, and purple. Anthocyanins can be found in red, purple, dark red plants such as berries and ornamental plants such as Butterfly pea (Clitoria ternatea). Butterfly pea (Clitoria ternatea) have a high enough potential for the food industry including being used as food coloring and used as traditional medicine. Process extraction anthocyanin of Butterfly pea (Clitoria ternatea) using different methods produces extracts with different total anthocyanins. In the future, further research is needed to be able to extract anthocyanin in telang flowers to produce an extract with high total anthocyanin and not easily damaged.
\end{abstract}

Keywords: Antosianin; Ekstraksi Antosianin; Pangan Fungsional Received: May 29, 2021 ; Accepted: July 8, 2021; Publish online: July 31, 2021

\section{Pendahuluan}

Antosianin merupakan bagian dari keluarga flavonoid yang berperan sebagai senyawa bioaktif karena memiliki sifat antioksidan (Bulgea dan Paramas 2018). Menurut Priska et al., (2018), merupakan zat warna alami yang termasuk golongan flavonoid dengan tiga atom oksigen. Antosianin bertanggungjawab dalam memberikan warna orange, merah, dan ungu pada tumbuhan. Antosianin pada tumbuhan dapat digunakan sebagai pewarna alami pada makanan, dimana menurut Armanzah and Hedrawati, (2016), warna merupakan factor kualitas yang penting bagi makanan. Selain sebagai pewarna antosianin merupakan antioksidan yang baik bagi tubuh diantaranya dapat menurunkan resiko terjadinya penyakit degenaratif, seperti kanker, dan jantung (Djaeni et al., 2017)

Antioksidan yang bersumber dari antosianin berfungsi sebagai peredam atau pemerangkap dimana molekul tersebut dapat bereaksi terhadap radikal bebas dan menetralkan radikal bebas. Reaksi oksidasi yang berlebihan pada tubuh kita dapat menyebabkan terbentuknya radikal bebas yang sangat aktif sehingga merusak struktur dan fungsi sel di dalam tubuh kita (Djaeni et al., 2017). Menurut Cahyaningsih, et al., (2019), Radikal bebas merupakan atom, molekul atau senyawa yang dapat berdiri sendiri yang memiliki electron tidak berpasangan, bersifat sangat reaktif dan tidak stabil. Ketika radikal bebas dalam jumlah yang banyak dapat mengganggu antioksidan alami yang terdapat di dalam tubuh yang menyebabkan gangguan sehingga dapat memutuskan rantai reduksi dan oksidasi yang mengakibatkan kerusakan oksidatif yang biasa kita kenal dengan istilah stress oksidatif. Oleh karena itu dengan mengkonsumsi makanan yang mengandung antioksidan seperti antosianin dapat membantu system pertahanan tubuh sehingga kembali normal (Djaeni et al., 2017). 
Antosianin dapat kita temukan pada tumbuhan yang berwarna merah, ungu, merah gelap seperti pada buah mulberry, blueberry, cherry, buah anggur serta beberapa jenis tanaman hias seperti bunga mawar, bunga kembang sepatu, dan bunga telang (Sangadji et al., 2017). Bunga telang merupakan salah satu tanaman hias yang memiliki bentuk unik dan khas yang biasa digunakan sebagai dekorasi baik di dalam ruangan maupun luar ruangan. Menurut Budiasih (2017) dalam Angriani (2019), bunga telang (Clitoria ternatea L.) sesuai dengan namanya Clitoria ternatea L merupakan bunga yang identic dengan warna ungu pada kelopaknya. Bunga telang termasuk tanaman yang sering merambat dan dapat kita temukan dipekarangan rumah, perkebunan, maupun di pinggir sawah. Bunga telang dapat tumbuh di daerah tropis seperti Asia, di Indonesia sendiri bunga telang banyak tumbuh di daerah seperti Trnate dan Maluku.

Menurut Angriani (2019), bunga telang dikenal dengan berbagai nama dalam bahasa inggris atau di daerah Inggri bunga telang dikenal dengan nama Butterfly pea. Sutedi (2013), menyatakan bahwa bunga telang (Clitoria ternatea L.) dapat tumbuh cukup baik pada kondisi kering dan terus menerus menghasilkan biji selama masa pertumbuhan, dengan jumlah produksi tanaman dan biji masing-masing sebesar 25-35 ton BK/ha dan 2,77 ton/ha pada umur panen 42 hari. Berdasarkan pendapat dari Angriani (2019), bunga telang (Clitoria ternatea L.) memiliki warna ungu serta biru dan merah karena bunga telang mengandung antosianin. Antosianin yang terdapat pada bunga telang memiliki kestabilang yang baik, sehingga sering digunakan sebagai pewarna alami pada makanan. Selain sebagai pewarna kandungan antosianin pada bunga telang memiliki fungsi sebagai salah satu sumber antioksidan yang berfungsi sebagai penangkal radikal bebas di dalam tubuh.

Antosianin yang terdapat di dalam bunga telang merupakan senyawa yang bersifat polar dimana senyawa tersebut dapat larut dalam pelarut yang bersifat polar seperti aquadest dan asam tartat Angriani (2019). Salah satu cara yang digunakan untuk dapat mengambil kandungan antosianin yang terdapat pada bunga telang adalag dengan cara ekstraksi. Berdasarkan hasil penelitian Hartono, et,al., (2012) bunga telang yang diekstrak menggunakan pelarut asam tartat menghasilkan bunga telang dengan kadar antosianin sebesar 820 ppm.

Menurut Mukhriani (2014) dalam Anggriani (2019), metode ekstraksi dapat dilakukan dengan beberapa cara diantaranya, maserasi, ultrasound, perkolasi, sochlet, reflux, dan destilasi uap. Anthika, et, al., (2015), melakukan penelitian mengenai ekstraksi antosianin pada bunga telang dengan menggunakan metedo ultrasound, dimana bunga telang yang diekstrak menggunakan metode ultrasound mengandung antosianin sebesar 35,41 ppm. Dari pernyataan di atas kita akan membuat suatu ulasan mengenai penggunaan pelarut serta metode ektrasi yang efektif untuk dapat menghasilkan ektrak antosianin dengan kadar yang tinggi pada bunga telang.

\section{Fungsi Antosianin Bagi Kesehatan}

Antosianin merupakan zat warna alami yang termauk golongan flavonoid dengan memiliki tiga atom karbon yang diikat oleh sebuah atom oksigen yang menghubungkan dua cincin aromatic benzene (C6H6) dalam struktur utamanya. (Tarone, et, al., 2020). Menurut Features, (2018), Antosianin mempunyai karakteristik kerangka karbon (C6C3C6) dengan struktur antosianin 2-fenil-benzofirilium dari garam flavilium. Struktur flavilium antosianin dapat dilihat pada gambar 1 .

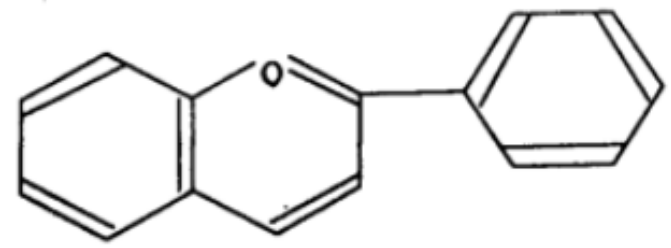

\section{Gambar 1. Flavilium Antosianin (Trojak dan Skowron, 2017)}

Menurut (Escher et al., 2020), Antosianin merupakan metabolit sekunder yang berasal dari golongan flavonoid yang banyak ditemukan dalam jumlah yang besar pada buah dan sayur. Antosianin dapat memberikan warna merah, violet, ungu, dan biru pada buah dan sayur. Antosianin memiliki sifat antioksidan, serta dapat digunakan sebagai antibakteri pada bahan pangan (Migliorini et al., 2019). Menurt Buelga dan Paramás (2018), Antosianin terdistribusi secara luas di dalam makanan nabati seperti sayur dan buah. Antosianin merupakan metabolit sekunder yang bersumber dari sumber alami seperti sayur dan buah yang aman untuk dikonsumsi.

Antioksidan yang terdapat pada antosianin dipercaya dapat mencegah beberapa penyakit di dalam tubuh, salah satunya adalah penyumbatan pada pembuluh darah. Cara kerja antosianin dalam mencegah penyumbatan pembuluh darah adalah dengan mencegah terjadinya oksidasi lemak jahat oleh antioksidan yang terdapat pada antosianin. Antosianin dapat menjadi pelindung bagi sel yang terdapat pada pembuluh darah sehingga tidak terjadi kerusakan pada pembuluh darah. Antosianin dapat melindungo lambung dari kerusakan, menghambat sel tumor, meningkatkan kemampuan penglihatan mata, serta berfungsi sebagai senyawa antiinflamasi pada otak. Pada intinya antioksidan yang terdapat pada antosianin dapat menangkal radikal bebas yang terdapat di dalam tubuh (Features, 2018). 
Menurut Sarmast and Jafari (2020), stress oksidatif merupakan suatu kondisi yang menunjukan oksigen reaktif (ROS) berada diluar kemampuan system pertahanan antioksidan. Stress oksidatif menyebabkan kerusakan ROS pada komponen penting seperti lemak, protein, dam DMA yang dapat menyebabkan karsinogenik. Menurut Pisochi dan Pop (2015), disisi lain ROS dapat menyebbabkan terjadinya peradangan melalui peningkatan ekpresi gen yang menyebabkan inflamasi. Beberapa studi menunjukan bahwa stress oksidatif berkaitan dengan beberapa penyakit degrenatif seperti penyumbatan pembuluh darah, diabetes, serta kanker pada tubuh manusia.

Beberapa uji klinis telah dilakukan pada manusia dilihat dari asupan antosianin atau beberapa bahan pangan yang mengandung antosianin yang dipercaya dapat melindungi tubuh dari penyakit kanker (Suarez, et al. 2014). Beberapa bukti didapatkan bahwa dengan mengkonsumsi bahan pangan yang mengandung antosianin ternyata dapat menurunkan kelebihan berat badan, melundungi tulang, pengurangan lemak dalam tubuh. Bahkan di Indonesia menurut Tucakovic, et al. (2018) dapat mencegah obersitas. Fungsi antosianin bagi kesehatan dapat dilitah pada Tabel 1 .

Tabel 1. Ringkasan Fungsi Antosianin Bagi Kesehatan

\begin{tabular}{|c|c|c|c|c|}
\hline $\begin{array}{c}\text { Subject } \\
\text { (Orang } \\
\text { ) }\end{array}$ & $\begin{array}{c}\text { Hasil } \\
\text { Penelitian } \\
\text { (Status } \\
\text { Kesehatan) }\end{array}$ & Durasi & $\begin{array}{c}\text { Sumber } \\
\text { Antosianin }\end{array}$ & Sumber \\
\hline 36 & $\begin{array}{l}\text { Menurunkan } \\
\text { Diabetes }\end{array}$ & $\begin{array}{c}6 \\
\text { Mingg } \\
\mathrm{u}\end{array}$ & $\begin{array}{l}\text { Minuman } \\
\text { Serbuk } \\
\text { Strawberry } \\
\text { Instant }\end{array}$ & $\begin{array}{c}\text { (Moazen } \text { et } \\
\text { al., 2013) }\end{array}$ \\
\hline 18 & $\begin{array}{c}\text { Menyehatka } \\
\text { n Tubuh }\end{array}$ & $\begin{array}{c}6 \\
\mathrm{u} \\
\mathrm{u}\end{array}$ & $\begin{array}{l}\text { Minuman } \\
\text { Serbuk } \\
\text { Strawberry } \\
\text { Instan }\end{array}$ & $\begin{array}{c}\text { (Riso et } \\
\text { al., 2013) }\end{array}$ \\
\hline 39 & $\begin{array}{c}\text { Menyehatka } \\
\text { n Pria } \\
\text { Perokok }\end{array}$ & $\begin{array}{c}4 \\
\text { Mingg } \\
\mathrm{u}\end{array}$ & $\begin{array}{c}\text { Minuman } \\
\text { Serbuk } \\
\text { Black } \\
\text { Rasberry } \\
\text { Instant }\end{array}$ & $\begin{array}{c}\text { (Park et } \\
\text { al. }, 2015)\end{array}$ \\
\hline 76 & $\begin{array}{c}\text { Menyehatka } \\
\text { n Tubuh }\end{array}$ & $\begin{array}{c}12 \\
\text { Mingg } \\
\mathrm{u}\end{array}$ & $\begin{array}{l}\text { Minuman } \\
\text { Serbuk } \\
\text { Teh Instant }\end{array}$ & $\begin{array}{l}\text { (Maeda- } \\
\text { Yamamoto } \\
\text { et al., } \\
\text { 2018) }\end{array}$ \\
\hline 10 & $\begin{array}{l}\text { Menyehatka } \\
\text { n Pengguna } \\
\text { Sepedah }\end{array}$ & $\underset{\mathrm{u}}{2}$ & $\begin{array}{c}\text { Buah Pulp } \\
\text { yang di } \\
\text { Pasteurisas } \\
\text { i }\end{array}$ & $\begin{array}{l}\text { (Terrazas } \\
\text { et al., } \\
\text { 2019) }\end{array}$ \\
\hline & $\begin{array}{c}\text { Menurunkan } \\
\text { Resiko } \\
\text { Diabetes }\end{array}$ & & $\begin{array}{c}\text { Jus Jeruk } \\
\text { (Ekstrak } \\
\text { Antosianin }\end{array}$ & $\begin{array}{l}\text { (Talagavad } \\
\text { i et al., } \\
\text { 2016) }\end{array}$ \\
\hline
\end{tabular}

Antosianin merupakan antioksidan yang baik bagi tubuh. Dapat dibuktikan dari beberapa uji klinis yang dilakukan antosianin dapat menyehatkan tubuh diantaranya menurunkan resiko diabetes, menyehatkan paru-paru pengguna sepedah bahkan dapat menyehatkan pria yang terbisa merokok ((Fallah, Sarmast and Jafari, 2020). Menurut Escher et al., (2020), antosianin merupakan senyawa yang larut dalam air atau bersifat polar. Sehingga kesesuaian pelarut yang digunakan akan berpengaruh terhadap ekstrak antosianin yang kita dapatkna. Berdasarkan penelitian Talagavadi et al., (2016), banyaknya antosianin yang terdapat pada buah dan sayur atau tumbuhan sebegian besar tergantung oleh beberapa factor seperti spesies, kondisi tumbuhan, varietas, ukuran buah, sayur, atau tumbuhan serta nutrisi dari pemupukan saat penanaman.

\section{Bunga Telang (Clitoria Ternatea L.)}

Bunga telang (Clitoria ternatea L.) tumbuhan yang dapat kita temukan di pekarangan atau di tepi hutan. Tumbuhan ini berasal dari Asia yang akan tumbuh pada iklin dimana tumbuhan ini biasa dijadikan sebagai tanaman hias. Menurut Anggriani (2019), di Indonesia bunga telang memiliki banyak nama seperti di daerah Sumatera dikenal dengan nama bunga biru, bunga kelentit, dan bunga telang, di Jawa tumbuhan tersebut dikenal dengan nama kembang teleng, menteleng, di Sulawesi dikenal dengan nama bunga talang, bunga temen rekeng, dan di Maluku dikenal dengan dama seyamagulele (Budiasih, 2017).

Menurut Mukherjee et al., (2008), Bunga telang dapat tumbuh dengan baik pada tanah berpasir dan pada curah hujan $500-900 \mathrm{~mm}$. bunga telang (clitoria ternatea) tumbuh baik bersama rumput-rumputan yang tinggi seperti rumput guinea dan rumput gajah. Menurut Cahyaningsih, et al., (2019)pertumbuhan bunga telang terbaik terjadi pada saat dibawa sinar matahari secara penuh. Habitat bunga telang biasanya tumbuh pada dataran rendah dimana kondisi tanah yang lembab atau agak lembab.

Bunga telang (Clitoria ternatea L.I) Merupakan bunga yang identic dengan warna ungi pada kelopaknya. Tanaman ini biasa tumbuh sebagai tanaman hias yang bias dijadikan sebagai obat mata dan pewarna makanan alami yang tidak berbahaya bagi tubuh (Anggriani, 2019). Menurut Cahyaningsih, et al. (2019), ternyata selain bunganya yang identic berwarna ungu tanaman ini ternyata memiliki kacang yang berwarna hijau. Menurut Maksana et al. (2017), warna pada bunga telang selain ungu ternyata memiliki warna biru dan merah yang disebabkan karena bunga telang mengandung senyawa antosianin. Kandungan antosianin pada bunga telang memiliki ketsabilan yang cukup baik. Bunga telang dapat dilihat pada gambar 2 . 


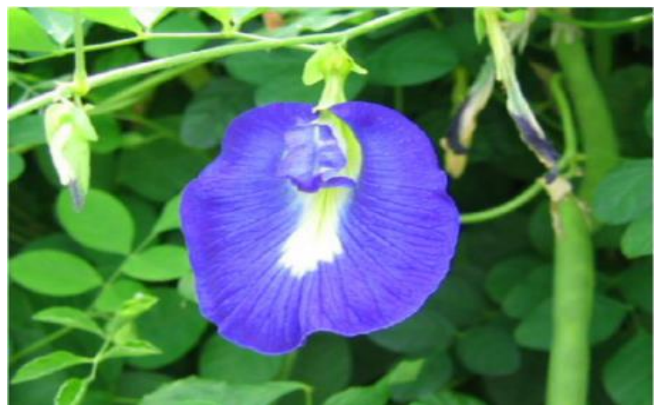

Gambar 2. Bunga Telang (Clitoria ternatea L.) (Manjula, 2013)

Selain sebagai pewarna antosianin yang terdapat pada bunga telang dapat bersifat sebagai antoiksidan yang dapat digunakan sebagai obat tradisional yang dapat bermanfaat bagi kesehatan tubuh. Menurut Maksana et al. (2017), kelebihan dari bunga telang cukup memberikan manfaat yang baik bagi industri pangan diantaranya dapat meningkatkan atribut mutu pada warna makanan bunga telang juga dapat memberikan manfaat kesehatan jika ditambahkan atau digunakan sebagai pewarna makanan. Menurut Mukhriani (2014), untuk memperoleh antosianin pada bunga telang salah satunya adalah dengan cara ekstraksi. Ekstraksi merupakan proses pemisahan suatu sampel atau komponen dengan pelarut yang digunakan. Antosianin merupakan senyawa yang bersifat polar sehingga akan terekstrak secara maksimal dengan pelarut yang sama-sama bersifat polar.

\section{Ekstraksi Antosianin Pada Bunga Telang (Clitoria Ternatea L.)}

Menurut Mukhriani (2014), Prinsip dari ekstraksi adalah melarutkan suatu senyawa sesuai dengan kemampuan pelarut dalam mengekstrak sentawa tersebut. Senyawa yang bersifat polar seperti antosianin akan larut maksimal dalam pelarut polar atau dikenal dengan senyawa yang larut di dalam air, sedangkan senyawa non polar akan larut secara maksimal pada pelarut yang bersifat non polar atau biasa kita kenal dengan senyawa yang larut pada lemak. Sehingga dapat disimpulkan bahwa kesesuaian pelarut yang digunakan akan berpengaruh secara maksimal terhadap ekstrak yang diinginkan. Menrut Pham et al (2019), ada 4 jenis ekstraksi yang bias kita gunakan untuk mengekstrak antosianin pada bunga telang diantaranya maserasi, ultrasound, perkolasi, sochlet, reflux, dan destilasi. Menurut Mukhriani (2014) dalam Anggriani (2019) metode ekstraksi yang tepat digunakan pada ekstraksi antosianin adalah maserasi, selain sederhana metode ini termasuk kedalam metode yang banyak digunakan serta dapat menghindari terjadinya kerusakan pada senyawa antosianin yang terdapat pada bunga telang.

Penggunaan pelarut polar seperti etanol yang bersifat polar ternyata dapat secara maksimal menghasilkan antosianin yang terdapat pada bunga telang (Nhut Pham et al., 2019). Menurut Ramdan, et al

(2017) penggunaan etanol pada konsentrasi 50\% menghasilkan intensitas warna yang tinggi pada ekstrak antosianin yang diekstrak menggunakan metode maserasi. Optimum ekstraksi dilakukan dengan perbandingan pelarut 15:500 dan suhu 60oC (Budiyati, et al 2012). Menurut Hartono penggunaan pelarut seperti asam tartarat pada konsentrasi $75 \%$ akan menghasilkan ekstrak antosianin yang tinggi pada bunga telang. Ekstrak antosianin pada bunga telang dapat dilihat pada Tabel 2.

Tabel 2. Ekstrak Antosianin Pada Bunga Telang

\begin{tabular}{|c|c|c|c|c|c|}
\hline \multicolumn{6}{|c|}{ (Clitoria Ternatea L.) } \\
\hline $\begin{array}{l}\text { Pelar } \\
\text { ut }\end{array}$ & $\begin{array}{c}\text { Lama } \\
\text { Ekstra } \\
\text { ksi }\end{array}$ & $\begin{array}{l}\text { Metode } \\
\text { Ekstrak } \\
\text { si }\end{array}$ & $\begin{array}{l}\text { Perlakua } \\
\text { n Terbaik }\end{array}$ & $\begin{array}{l}\text { Total } \\
\text { Antosi } \\
\text { anin } \\
(\mathrm{Ppm})\end{array}$ & Sumber \\
\hline Air & - & $\begin{array}{c}\text { Masera } \\
\text { si }\end{array}$ & $\begin{array}{c}\text { Perbandi } \\
\text { ngan } \\
\text { Bunga } \\
\text { Telang } \\
\text { dengan } \\
\text { Air (15: } \\
500)\end{array}$ & 6,35 & $\begin{array}{l}\text { (Zussiva, } \\
\text { et al., } \\
2012 \text { ) }\end{array}$ \\
\hline $\begin{array}{c}\text { Air } \\
\text { dan } \\
\text { Asa } \\
\mathrm{m}\end{array}$ & & $\begin{array}{c}\text { Masara } \\
\text { si }\end{array}$ & $\begin{array}{l}\text { Antosian } \\
\text { in } 0,75 \%\end{array}$ & 820 & $\begin{array}{l}\text { (Hartono, } \\
\text { et al., } \\
\text { 2012) }\end{array}$ \\
\hline $\begin{array}{c}\text { Tarta } \\
\mathrm{t}\end{array}$ & & & & & \\
\hline Air & $\begin{array}{c}30 \\
\text { menit }\end{array}$ & $\begin{array}{c}\text { ultraso } \\
\text { und }\end{array}$ & $\begin{array}{l}\text { Ultrasou } \\
\text { nd } \\
\text { selama } \\
30 \text { menit }\end{array}$ & 35,41 & $\begin{array}{l}\text { (Anthika, } \\
\text { et } \text { al., } \\
\text { 2015) }\end{array}$ \\
\hline $\begin{array}{c}\text { Etan } \\
\text { ol }\end{array}$ & $\begin{array}{c}40 \\
\text { Menit } \\
-70 \\
\text { Menit }\end{array}$ & $\begin{array}{c}\text { Masera } \\
\text { si }\end{array}$ & 45 Menit & 132,76 & $\begin{array}{c}\text { Pham et } \\
\text { al., (2019) }\end{array}$ \\
\hline $\begin{array}{l}\text { Air } \\
\text { dan } \\
\text { Meta } \\
\text { nol }\end{array}$ & $\begin{array}{c}24 \\
\text { jam }\end{array}$ & $\begin{array}{c}\text { Masera } \\
\text { si } \\
\text { dengan } \\
\text { dengan } \\
\text { variasi } \\
\text { Ph } \\
\text { yang } \\
\text { berbed } \\
\text { a }\end{array}$ & $\begin{array}{c}\text { Maserasi } \\
\text { Pada Ph } \\
1-3 \\
\text { menggun } \\
\text { akan } \\
\text { pelarut } \\
\text { metanol }\end{array}$ & 14,95 & $\begin{array}{l}\text { (Wiyanto } \\
\text { ko and } \\
\text { Astuti, } \\
2020 \text { ) }\end{array}$ \\
\hline Air & $\begin{array}{c}30- \\
90 \\
\text { Menit }\end{array}$ & $\begin{array}{c}\text { Masera } \\
\text { si dan } \\
\text { Ultra } \\
\text { Sound }\end{array}$ & $\begin{array}{l}\text { Ultra } \\
\text { Sound } \\
\text { selama } \\
90 \text { Menit }\end{array}$ & 1430 & $\begin{array}{c}\text { (Syafa'At } \\
\text { ullah et } \\
\text { al., 2020) }\end{array}$ \\
\hline $\begin{array}{l}\text { Air } \\
\text { dan }\end{array}$ & $\begin{array}{l}15, \\
30,\end{array}$ & $\begin{array}{c}\text { Masera } \\
\text { si }\end{array}$ & $\begin{array}{l}\text { Etanol } \\
\text { Selama }\end{array}$ & 143,29 & $\begin{array}{l}\text { (Pham et } \\
\text { al., 2019) }\end{array}$ \\
\hline $\begin{array}{c}\text { Etan } \\
\text { ol }\end{array}$ & $\begin{array}{c}45, \\
60, \\
\text { dan } \\
75\end{array}$ & & 30 Menit & & \\
\hline Air & $\begin{array}{c}24 \\
\text { jam }\end{array}$ & $\begin{array}{c}\text { Masera } \\
\text { si }\end{array}$ & $\begin{array}{l}\text { Maserai } \\
24 \text { jam }\end{array}$ & 53,02 & $\begin{array}{l}\text { (Hariadi } \\
\text { et al., } \\
2018 \text { ) }\end{array}$ \\
\hline Air & $\begin{array}{l}30- \\
150\end{array}$ & $\begin{array}{l}\text { Ultraso } \\
\text { und }\end{array}$ & $\begin{array}{c}\text { Ultrasou } \\
\text { nd } 150\end{array}$ & 1126 & $\begin{array}{l}\text { (Chong } \\
\text { and }\end{array}$ \\
\hline
\end{tabular}




\begin{tabular}{|c|c|c|c|c|c|}
\hline & menit & $\begin{array}{c}\text { dan } \\
\text { Masera }\end{array}$ & Menit & & $\begin{array}{l}\text { Gwee, } \\
2015)\end{array}$ \\
\hline Air & $\begin{array}{c}3 \\
\text { Menit }\end{array}$ & $\begin{array}{c}\text { Masera } \\
\text { si }\end{array}$ & $\begin{array}{c}\text { Maserasi } \\
3 \text { Menit }\end{array}$ & 106,62 & $\begin{array}{l}\text { (Netramai } \\
\text { and } \\
\text { Kijchaven } \\
\text { gkul, } \\
2020 \text { ) }\end{array}$ \\
\hline
\end{tabular}

\section{Kesimpulan}

Antosianin merupakan suatu senyawa yang membentuk zat warna alami pada tumbuhan dalam memberikan warna orange, merah, serta ungu. Antosianin dapat kita temukan pada tumbuhan berwarna merah, ungu, merah gelap seperti pada buah berry serta tanaman hias seperti bunga telang. Bunga telang memiliki potensi yang cukup tinggi bagi inudustri pangan diantaranya digunakan sebagai pewarna makanan dan digunakan sebagai obat tradisional.. Antosianin yang terdapat pada bunga telang bersiafat polar sehingga dapat larut dalam pelarut dimana senyawa polar akan mudah terekstrak secara maksimal dengan pelarut yang bersifat polar. Proses ekstraksi yang digunakan menggunakan pelarut yang berbeda, lama ekstraksi yang berebda serta motedo ekstraksi yang berbeda baik maserasi maupun ultrasound menghasilkan ekstrak dengan total antosianin yang berbeda pada bunga telang. Kedepanya kombinasi metode ekstraksi antosianin perlu dapat dilakukan penelitian untuk didapatkan ekstrak total antosianin yang paling tinggi pada bunga telang serta memiliki kestabilan yang tinggi dalam waktu yang lama.

\section{Daftar Pustaka}

1. Angriani, L. (2019) 'Potensi ekstrak bunga telang (Clitoria ternatea) sebagai pewarna alami lokal pada berbagai industri pangan', Canrea Journal, 2(2), pp. 32-37.

2. Anthika, B., Kusumocahyo, S. P. and Sutanto, H. (2015) 'Ultrasonic Approach in Clitoria ternatea (Butterfly Pea) Extraction in Water and Extract Sterilization by Ultrafiltration for Eye Drop Active Ingredient', Procedia Chemistry, 16(6), pp. 237244. doi: 10.1016/j.proche.2015.12.046.

3. Armanzah, R. S. and Hedrawati, T. Y. (2016) 'Pengaruh Waktu Maserasi Zat Antosianin Sebagai Pewarna Alami dari Ubi Jalar Ungu (Ipomoea batatas L. Poir)', Seminar Nasional Sains dan Teknologi, (November), pp. 1-10. Available at: jurnal.umj.ac.id/index.php/semnastek\%0Ap-ISSN.

4. Chong, F. C. and Gwee, X. F. (2015) 'Ultrasonic extraction of anthocyanin from Clitoria ternatea flowers using response surface methodology', Natural Product Research, 29(15), pp. 1485-1487. doi: 10.1080/14786419.2015.1027892.
5. Djaeni, M. et al. (2017) 'Ekstraksi Antosianin dari Kelopak Bunga Rosella (Hibiscus sabdariffa L.) Berbantu Ultrasonik: Tinjauan Aktivitas Antioksidan Ultrasonic Aided Anthocyanin Extraction of Hibiscus sabdariffa L. Flower Petal: Antioxidant Activity', Jurnal Aplikasi Teknologi Pangan, 6(3), p. 2017. doi: 10.17728/jatp.236.

6. Erna Cahyaningsih, Putu Era Sandhi K., P. S. (2019) 'Skrinning fitokimia dan uji aktivitas antioksidan ekstrak etanol bunga telang (Clitoria ternatea L.) dengan metode spektrofotometri UVVis', Ilmiah Medicamento, 5(1), pp. 51-57.

7. Escher, G. B. et al. (2020) 'Phenolic composition by UHPLC-Q-TOF-MS/MS and stability of anthocyanins from Clitoria ternatea L. (butterfly pea) blue petals', Food Chemistry. Elsevier Ltd, 331, p. 127341. doi: 10.1016/j.foodchem.2020.127341.

8. Fallah, A. A., Sarmast, E. and Jafari, T. (2020) 'Effect of dietary anthocyanins on biomarkers of oxidative stress and antioxidative capacity: A systematic review and meta-analysis of randomized controlled trials', Journal of Functional Foods. Elsevier, 68(March), p. 103912. doi: 10.1016/j.jff.2020.103912.

9. Features, S. (2018) 'Anthocyanins', pp. 1-12. doi: 10.1016/B978-0-12-814026-0.21609-0.

10. Hariadi, H. et al. (2018) 'Comparison of phytochemical characteristics pigmen extract (Antosianin) sweet purple potatoes powder (Ipomoea batatas L) and clitoria flower (Clitoria ternatea) as natural dye powder', Journal of Pharmacognosy and Phytochemistry, 7(4), pp. 3420-3429.

11. Hartono, M. A., Purwijantiningsih, L. M. E. and Pranata, S. (2012) 'Pemanfaatan ekstrak bunga telang (Clitoria ternatea L.) sebagai pewarna alami es lilin Utilization of Extract Butterfly Pea Flowers (Clitoria ternatea L.) As Natural Colorant of Ice Lolly', pp. 1-15.

12. Maeda-Yamamoto, M. et al. (2018) 'A randomized, placebo-controlled study on the safety and efficacy of daily ingestion of green tea (Camellia sinensis 1.) cv. "Yabukita" and "Sunrouge" on eyestrain and blood pressure in healthy adults', Nutrients, 10(5), pp. 1-13. doi: 10.3390/nu10050569.

13. Migliorini, A. A. et al. (2019) 'Red Chicory (Cichorium intybus) Extract Rich in Anthocyanins: Chemical Stability, Antioxidant Activity, and 
Antiproliferative Activity In Vitro', Journal of Food Science, 84(5), pp. 990-1001. doi: 10.1111/1750-3841.14506.

14. Moazen, S. et al. (2013) 'Effects of freeze-dried strawberry supplementation on metabolic biomarkers of atherosclerosis in subjects with type 2 diabetes: A randomized double-blind controlled trial', Annals of Nutrition and Metabolism, 63(3), pp. 256-264. doi: 10.1159/000356053.

15. Mukherjee, P. K. et al. (2008) 'The Ayurvedic medicine Clitoria ternatea-From traditional use to scientific assessment', Journal of Ethnopharmacology, 120(3), pp. 291-301. doi: 10.1016/j.jep.2008.09.009.

16. Netramai, S. and Kijchavengkul, T. (2020) 'Development of Colorimetric Film with Butterfly Pea ( Clitoria ternatea L .) Development of Colorimetric Film with Butterfly Pea ( Clitoria ternatea L . ) Extract for Application in Intelligent Packaging', (June).

17. Nhut Pham, T. et al. (2019) 'Extraction of anthocyanins from Butterfly pea (Clitoria ternatea L. Flowers) in Southern Vietnam: Response surface modeling for optimization of the operation conditions', IOP Conference Series: Materials Science and Engineering, 542(1). doi: 10.1088/1757-899X/542/1/012032.

18. Park, E. et al. (2015) 'Effects of Korean black raspberry supplementation on oxidative stress and plasma antioxidant capacity in healthy male smokers', Journal of Functional Foods. Elsevier Ltd, 16, pp. 393-402. doi: 10.1016/j.jff.2015.04.047.

19. Pham, T. N. et al. (2019) 'Effect of various factors on extraction efficiency of total anthocyanins from Butterfly pea (Clitoria ternatea L. Flowers) in Southern Vietnam', IOP Conference Series: Materials Science and Engineering, 544(1). doi: 10.1088/1757-899X/544/1/012013.

20. Priska, M. et al. (2018) 'REVIEW : ANTOSIANIN DAN PEMANFAATANNYA', 6, pp. 79-97.

21. Riso, P. et al. (2013) 'Effect of a wild blueberry (Vaccinium angustifolium) drink intervention on markers of oxidative stress, inflammation and endothelial function in humans with cardiovascular risk factors', European Journal of Nutrition, 52(3), pp. 949-961. doi: 10.1007/s00394-012-0402-9.

22. Sangadji, I. et al. (2017) 'Kandungan Antosianin Di Dalam Mahkota Bunga Beberapa Tanaman
Hias', Jurnal Biology Science \& Education 2017 INSUN S. dkk BIOLOGI SEL, 6(2), p. 118.

23. Sutedi, E. (2013) 'POTENSI KEMBANG TELANG ( Clitoria ternatea )', 16002(Nulik 2009), pp. 51-62.

24. Syafa'Atullah, A. Q. et al. (2020) 'Anthocyanin from butterfly pea flowers (Clitoria ternatea) by ultrasonic-assisted extraction', AIP Conference Proceedings, 2237(June). doi: 10.1063/5.0005289.

25. Talagavadi, V. et al. (2016) 'Cyanidin-3-O- $\beta$ glucoside and protocatechuic acid activate AMPK/mTOR/S6K pathway and improve glucose homeostasis in mice', Journal of Functional Foods. Elsevier Ltd, 21, pp. 338-348. doi: 10.1016/j.jff.2015.12.007.

26. Tarone, A. G., Cazarin, C. B. B. and Marostica Junior, M. R. (2020) 'Anthocyanins: New techniques and challenges in microencapsulation', Food Research International. Elsevier Ltd, 133, p. 109092. doi: 10.1016/j.foodres.2020.109092.

27. Terrazas, S. I. B. M. et al. (2019) 'Açai pulp supplementation as a nutritional strategy to prevent oxidative damage, improve oxidative status, and modulate blood lactate of male cyclists', European Journal of Nutrition. Springer Berlin Heidelberg. doi: 10.1007/s00394-019-02138-7.

28. Trojak, M. and Skowron, E. (2017) 'Role of anthocyanins in high-light stress response', Wsn, 81(2), pp. 150-168. Available at: www.worldscientificnews.com.

29. Wiyantoko, B. and Astuti, A. (2020) 'Butterfly Pea (Clitoria Ternatea L.) Extract as Indicator of AcidBase Titration', IJCA (Indonesian Journal of Chemical Analysis), 3(1), pp. 22-32. doi: 10.20885/ijca.vol3.iss1.art4.

30. Zussiva, A., Bertha, K. L. and Budiyati, C. S. (2012) 'Ekstraksi dan Analisis Zat Warna Biru (Anthosianin Anthosianin) dari Bunga Telang (Clitoria Ternatea) Sebagai Pewarna Alami', Jurnal Teknologi Kimia dan Industri, 1(1), pp. 356-365. 